Research Article

\title{
Pathogenicity severity of Iranian isolates of Rhizoctonia solani in Burren potato cultivar
}

\author{
DORNA FORGHANI ${ }^{1 凶}$, EIDI BAZGIR $^{1}$, MEHDI NASR ESFAHANI $^{2}$, \\ MOSTAFA DARVISHNIA ${ }^{1}$ \\ 1- Department of Plant Protection, Faculty of Agriculture, Lorestan University, , \\ Khorramabad, Iran \\ 2- Plant Pests and Diseases Research Department, Isfahan Agricultural and Natural \\ Resources Research Center, Isfahan, Iran
}

Received: 08.13.2020

Accepted: 01.26.2021

Forghani D, Bazgir E, Nasr Esfahani M, Darvishnia M (2020) Pathogenicity severity of Iranian isolates of Rhizoctonia solani in Burren potato cultivar. Plant Pathology Science 9(2):63-72. DOI: 10.2982/PPS.9.2.63.

\begin{abstract}
Introduction: Rhizoctonia solani Kühn is a soil borne fungus that causes stem canker and black scurf and severely damages crop in various potato growing areas in Iran. The aim of this study was to investigate the pathogenicity of various fungal isolates from different potato growing areas in Iran on the Burren cultivar. Material and Methods: In this study, The pathogenicity of 70 isolates of Rhizoctonia solani from major potato growing areas in Iran including the provinces of Ardabil, Isfahan, Fars, Kurdistan, Kerman, Lorestan and Hamedan was investigated on the potato cultivar 'Burren' in completely randomized design experiment under greenhouse conditions. Results: The analysis of variance showed that the pathogenicity of the isolates was very different at probability level of $1 \%$ is significant, and therefore they were divided into different groups. Conclusions: The isolates of Ardabil-1, Ardabil-5, Isfahan-14, Fars-26, Fars29, Kurdistan-34, Kurdistan-39, Kurdistan-40, Kerman-47 and Hamedan-66 had the highest pathogenicity, while the isolates Fars-21, Isfahan-20, Hamedan-65 and Isfahan18 showed the lowest pathogenicity, respectively.
\end{abstract}

Key words: Potato, Burren cultivar, Pathogenicity, Rhizoctonia solani

$\triangle$ Corresponding author: dornaforghani140@gmail.com 


\section{مقاله يزوهشى}

\section{شدت بيمارىزايى جدايههاى ايرانى Rhizoctonia solani در سيبزمينى رقم بورن}

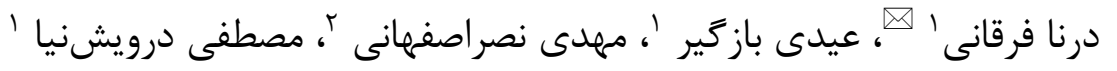

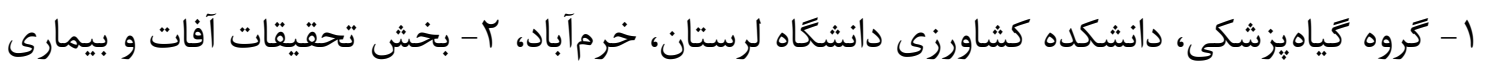
هاى گَياهى، مركز تحقيقات كشاورزى و منابع طبيعى استان اصفهان

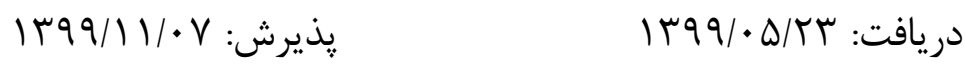

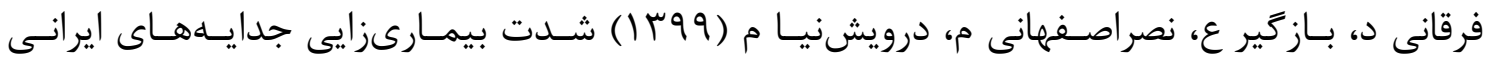
Rhizoctonia solani

DOI:10.2982/PPS.9.2.63.

مقدمه: Rhizoctonia solani Kühn يك قارج خاكزاد عامل يوسيدگى ريشه سيبزمينى اسـت كـه هرساله خسارت زيادى به محصول سيبزمينى در منطقههاى مختلف ايران وارد مىسازد. هدف از اين

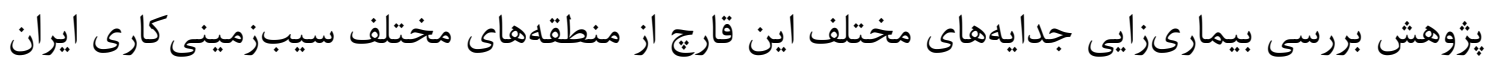

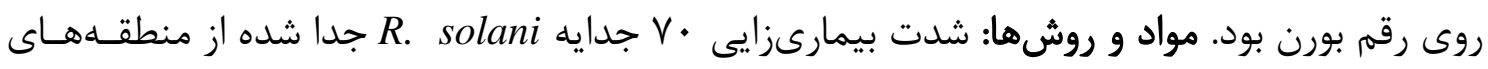

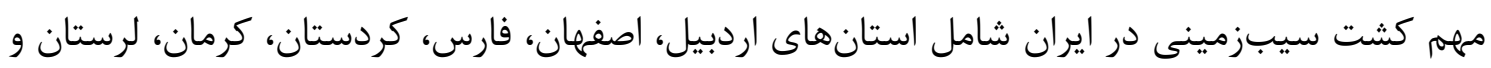

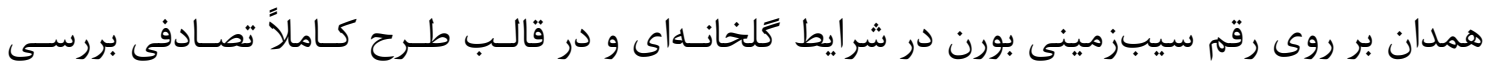

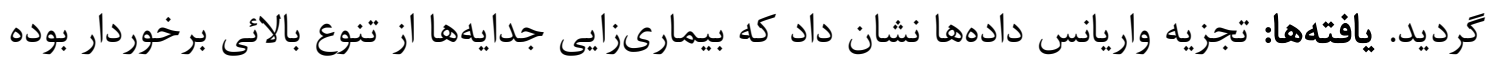

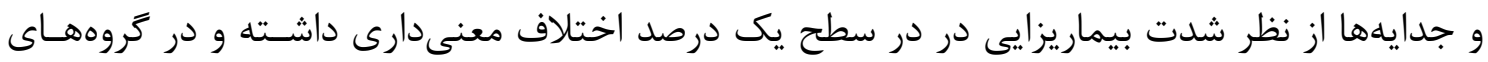

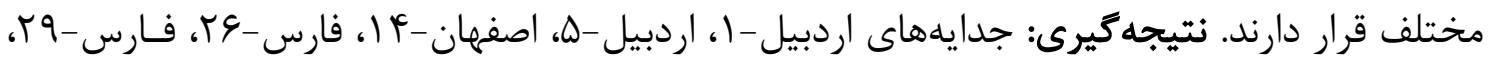

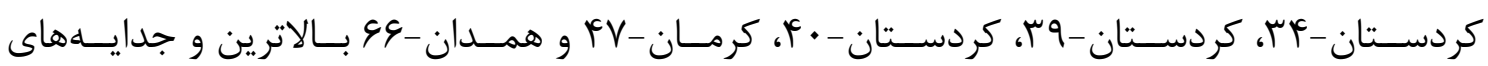

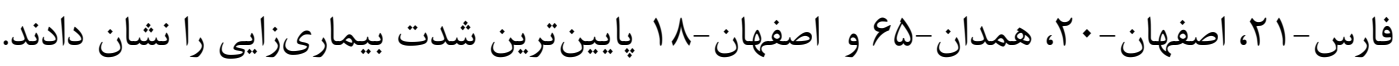

وازگًان كليدى: سيبزمينى، رقم بورن، بيمارىزايى، Rhizoctonia solani

\section{Introduction}

مقدمه

سيبزمينى با نام علمى Solanum tuberosum L. تيره بادمجانيـان Solanaceae كيـاهى بـا ارزش اقتصادى و مهم كشاورزى است (Spooner et al. 2005). براساس آمار رسمى سـازمان فـائو در سـال

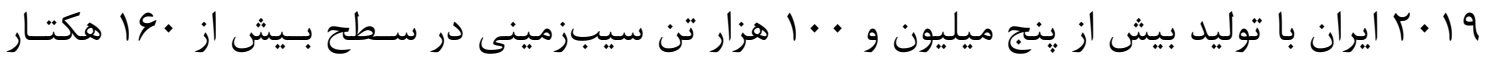
رتبه سيزدهم توليدكنندكان جهان را به خود اختصاص داده است.

ه dornaforghani140@gmail.com 
رقمهاى گَوناگون سيبزمينى در ايران با خصوصيات رشدى متنوع و با درجـات مختلفـى از مقاومست نسبت به بيمارىهاى گياهى كشت مىشوند. يكى از رقمهـاى سـيبزمينى در ايسران مناسـب جهـت كشت بهاره، رقم بورن "Burren" است. بورن يك رقم سيبزمينى بذرى با خصوصيات زير است: غـده تخممرغى كشيده، يوسته كرمى رنت و نيمهصاف، پايه جوانهها بنفشرنگ، ارتفاع بوته متوسط و كلها

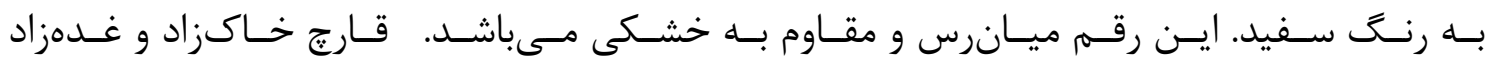
Rhizoctonia solani Kühn

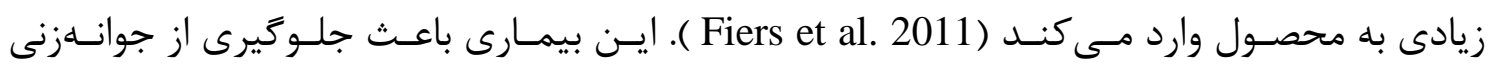
جشمها، تأخير در رشد بوتهها، كاهش جشمعير تعداد ساقه، كاهش طول استولون و بدشـكلى غـدهها مىشود. نشانههاى بيمارى بلصورت ايجاد شانكر روى استولون و تشـكيل اسـكلروتهاى متعـدد روى غده سيبزمينى ظاهر مىشوند (Stevenson et al. 2001). تاكنون سا گروه آناستوموزى در اين قارج شناسـايى شـده، كـه حـروه غالـب بيمـارىزا در سـيبزمينى BG3-PT اسـت ( Bartz et al. 2010, Kuninaga et al. 2000, Woodhall et al. 2008 ايران و اهميت اين بيمارى، روشهاى متعددى براى مهار آن معرفى شده است، ليكن اكثر اين روشها بر קايه استفاده از سمهاى شيميايى است كه در نتيجه باعث آلودگى محيطزيست مىشود. لذا استفاده از روشهاى جايكزين مهار شيميايى از جمله استفاده از رقمهاى مقـاوم مسىتوانـد در جهــت كـاهش

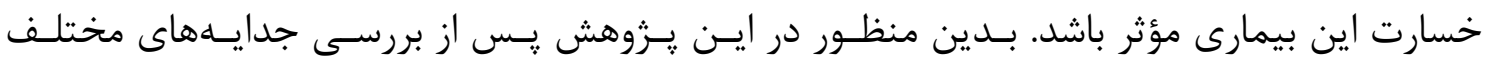
R. solani رقم ير كاربرد "بورن" در كلخانه مورد بررسى قرار كرفت.

\section{Material and Methods}

مواد و روشها

\section{R. solani نمونهبردارى و جداسازى}

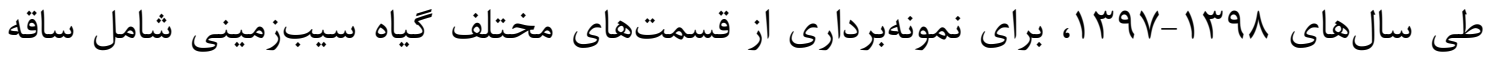
زيرزمينى، استولون، ريشه و همزجنين، غدههاى آلوده از مزارع سيبزمينى در مناطق مختلف استانهاى اردبيل، اصفهان، فارس، كردستان، كرمان، لرستان و همدان، بازديد صورت كرفت. نمونههاى آلوده ينج منطقه از هر استان و به تعداد ها نمونه از هر منطقه، جمعآورى و دركيسههاى نايلونى به آزمايشعاه انتقال داده شدند. نمونهای انتخابى در شرايط استريل در داخل تشتكهاى يترى 9 سانتىمترى حاوى محيط كشت PDA (عصاره سيبزمينى دكستروز آكار) كشت شدند. تشتكهاى يترى در دماى F T درجه سانتى گراد و در شرايط تاريكى در انكوباتور نتخهدارى و روزانه 
R. solani مورد بازديد قرار كرفتند. خالصسازى قارج از يركنههاى داراى مشخصات ظاهرى قارج

روى محيط كشت آب آكار (WA) به روش نوك ريسه انجام شد. (Ganeshamoorthi et al. 2013).

\section{تعيين شدت بيماريزايى جدايههاى Rolani}

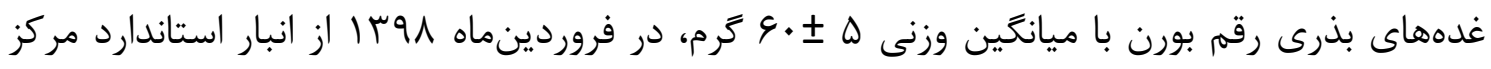
تحقيقات كشاورزى و منابع طبيعى استان اصفهان واقع در شهرك صنعتى محمودآباد اصفهان تهيه كرديد. غدهها در كيسههاى يلاستيكى در يخجال تا زمان استفاده نگَهدارى شدند. غدههاى كاملاً سالم، عارى از هر گونه نشانه يوسيدگى، اسكلرت انتخاب شده و قبل از كاشت با استفاده از محلول هييوكلريت سديم • 1\% به مدت · ا دقيقه ضدعفونى گرديده و سيس با استفاده از آبمقطر دو بار استريل شستشو داده و روى كاغذ صافى استريل خشك شدند.

محل آزمايش كلخانهاى و كلدانهاى موردنياز با محلول هييوكلريت سديم • 1\% بهطور كامل ضدعفونى شدند. خاى موردنياز جهت كشت در آون استريل كرديد. غدههاى ضدعفونى شده در كلدانهاى حاوى خاى سترون كاشته شدند. گلخانه داراى دماى ميانگين IVIY درجه سلسيوس و

$$
\text { رطوبت نسبى •و درصد و r| |F أ ساعت دوره روشنايى بود. }
$$

هس از كشت نمونههاى قارجى، از هر استان تعداد • ا جدايه و در مجموع •V جدايه جهت مايهزنى در محيط كلخانه استفاده گرديد. يس از قرار گرفتن غدهها در گلدانهاى استريل، ه قطعه به قطر هـ ميلىمتر از حاشيه يركنه ·ل روزه قارج در محيط كشت PDA، در اطراف غدهها قرار داده شد (Prasad and Eizenga 2008 ( ) سيس به ضخامت حدود ه سانتىمتر خاك استريل مرطوب (شن، ماسه و پييت به نسبت 1:؟:() روى غدهها ريخته شد. بعد از كذشت سه هفته آبيارى و مراقبت، ساقهها بهآرامى از خاى داخل كَلدانها بيرون آورده شدند، خاك اطراف آنها شستشو شده و شدت آلودگى حاصل از جدايه قارجى روى آنها مورد بررسى قرار گرفت. آزمايش در شرايط گلخانهاى و در قالب طرح كاملاً تصادفى با ه تكرار و • Vيمار (تيمارها همان جدايههاى قارجى است) انجام شد. جهت اطمينان از يافته ها به دست آمده آزمايش يك بار ديخر هم تكرار گرديد. جداسازى مجدد قارج آلوده كننده از نمونههاى بيمار براى تأييد اصول كخ انجام شد (Banville et al. 1996). درصد شدت بيمارى يا Percent disease severity (PDS) در تيمارها و تكرارها به تفكيك شش هفته

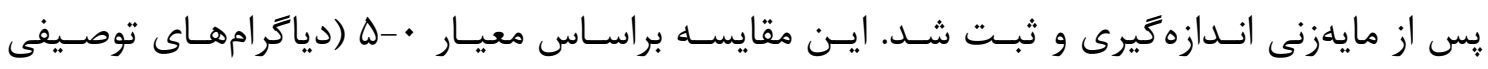
انستيتوى ملى كياهشناسى كشاورزى انگليس (National Institute of Agriculture Botany:NIAB)

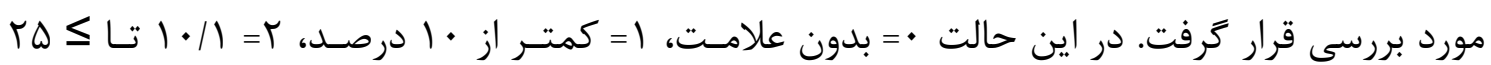


درصد، r= ساقههاى زيرزمينى در نظر گرفته شد (NIAB 1985).

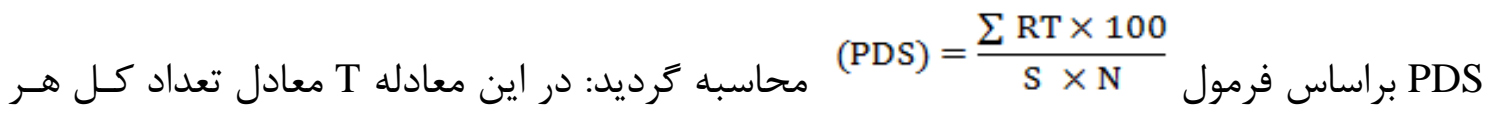
ساقه در هر خروه؛ R معادل معيار شدت بيمارى؛ N معادل تعداد كل ساقههاى آزمايشى و S معـادل بالاترين معيار است ( Woodhall et al. 2008 ). ميانگين درصد شدت بيمارى در گياهان سـيبزمينى رقم بورن به جدايههاى مختلف قارج Rolani . براى استانهاى موردنظر نيز محاسبه كرديـد. تجزيـه واريانس(ANOVA) تمامى دادهها انجام گرديد. مقايسه ميانخين بهوسيله آزمون جنددامنسهاى دانكـن (Doghaddam et al. 2019 (DAS با استفاده از نرمافزار (DMRT)

\section{Results}

يافتهها

بررسى • V جدايه از استانهاى اردبيل، اصفهان، فارس، كردستان، كرمان، لرستان و همدان، نشان داد كه و9 جدايه روى رقم بورن بيمارىزا هستند. نشانه شانكر خشك يس از حدود •r روز از مايهزنى روى ساقههاى زيرزمينى سيبزمينى رقم بورن مشاهده گرديد (شكل (). در نمونه شاهد هيج گونه نشانهاى از بيمارى مشاهده نشد. تجزيه واريانس دادههاى آزمايش نشان داد كه اختلاف معنى دارى (P=0.01)

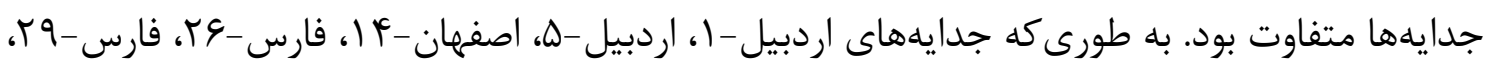
كردستان-r

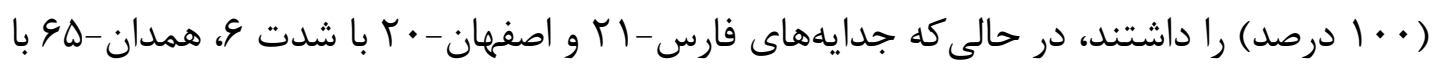

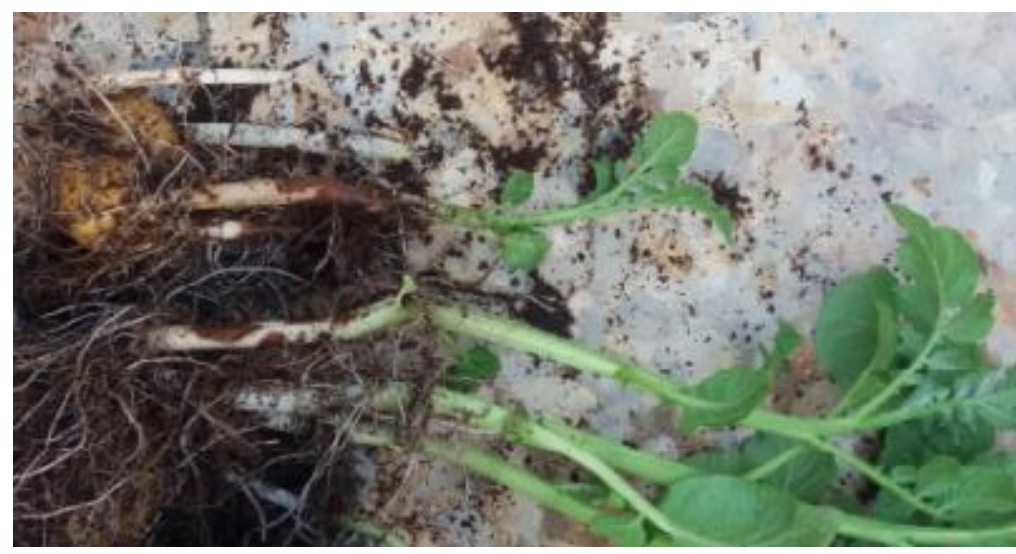

شكل ا. بيمارىزايى جدايه ايرانى قارج Rhizoctonia solani روى سيبزمينى رقم بورن.

Figure 1. Pathogenicity of an Iranian Rhizoctonia solani isolate on Burren potato cultivar. 
جدول ا. شدت بيمارىزايى جدايههاى ايرانى Rhizoctonia solani روى رقم بورن سيبزمينى (اعداد

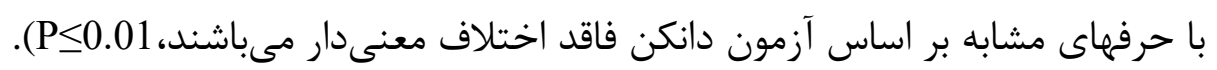

Table 1. Pathogenicity of Iranian Rhizoctonia solani isolates on Burren potato cultivar.

\begin{tabular}{|c|c|c|c|c|c|}
\hline Number & Location & $\begin{array}{l}\text { Percent } \\
\text { Disease } \\
\text { severity }\end{array}$ & Number & Location & $\begin{array}{l}\text { Percent } \\
\text { Disease } \\
\text { severity }\end{array}$ \\
\hline 1 & Ardabil, Ardabil & $100 \mathrm{a}^{*}$ & 36 & Ghorveh, Kordestan & $90 \mathrm{ab}$ \\
\hline 2 & Nir, Ardabil & $40 \mathrm{e}-\mathrm{g}$ & 37 & Dehgolan, Kordestan & $95 \mathrm{ab}$ \\
\hline 3 & Nir, Ardabil & $45 \mathrm{~d}-\mathrm{g}$ & 38 & Dehgolan, Kordestan & $95 \mathrm{ab}$ \\
\hline 4 & Ardabil, Ardabil & $95 \mathrm{ab}$ & 39 & Dehgolan, Kordestan & $100 \mathrm{a}$ \\
\hline 5 & Nir, Ardabil & $100 \mathrm{a}$ & 40 & Ghorveh, Kordestan & $100 \mathrm{a}$ \\
\hline 6 & Namin, Ardabil & $45 \mathrm{~d}-\mathrm{g}$ & 41 & Jiroft, Kerman & $60 \mathrm{~b}-\mathrm{e}$ \\
\hline 7 & Namin, Ardabil & 70 a-d & 42 & Jiroft, Kerman & $95 \mathrm{ab}$ \\
\hline 8 & Ardabil, Ardabil & $95 \mathrm{ab}$ & 43 & Jiroft, Kerman & $55 \mathrm{c}-\mathrm{f}$ \\
\hline 9 & Namin, Ardabil & $40 \mathrm{e}-\mathrm{g}$ & 44 & Jiroft, Kerman & $80 \mathrm{a}-\mathrm{c}$ \\
\hline 10 & Ardabil, Ardabil & $80 \mathrm{a}-\mathrm{c}$ & 45 & Jiroft, Kerman & $95 \mathrm{ab}$ \\
\hline 11 & Chadegan, Isfahan & $80 \mathrm{a}-\mathrm{c}$ & 46 & Jiroft, Kerman & $30 \mathrm{f}-\mathrm{h}$ \\
\hline 12 & Chadegan, Isfahan & $27 \mathrm{gh}$ & 47 & Jiroft, Kerman & $100 \mathrm{a}$ \\
\hline 13 & Fereydan, Isfahan & $90 \mathrm{ab}$ & 48 & Jiroft, Kerman & $90 \mathrm{ab}$ \\
\hline 14 & Semirom, Isafahan & $100 \mathrm{a}$ & 49 & Jiroft, Kerman & $90 \mathrm{ab}$ \\
\hline 15 & Golpayegan, Isfahan & 65 a-e & 50 & Jiroft, Kerman & $95 \mathrm{ab}$ \\
\hline 16 & Golpayegan, Isfahan & $90 \mathrm{ab}$ & 51 & Noor Abad, Lorestan & $90 \mathrm{ab}$ \\
\hline 17 & Golpayegan, Isfahan & $90 \mathrm{ab}$ & 52 & Azna, Lorestan & $95 \mathrm{ab}$ \\
\hline 18 & Damaneh, Isfahan & $0 \mathrm{j}$ & 53 & Aligoodarz, Lorestan & $80 \mathrm{a}-\mathrm{c}$ \\
\hline 19 & Damaneh, Isfahan & $22 \mathrm{gh}$ & 54 & Alashtar, Lorestan & 14 hi \\
\hline 20 & Semirom, Isafahan & $6 \mathrm{ij}$ & 55 & Khoram Abad, Lorestan & $80 a-c$ \\
\hline 21 & Lar, Fars & $6 \mathrm{ij}$ & 56 & Khoram Abad, Lorestan & 65 a-e \\
\hline 22 & Lar, Fars & $22 \mathrm{gh}$ & 57 & Azna, Lorestan & $90 a b$ \\
\hline 23 & Lamard, Fars & $90 \mathrm{ab}$ & 58 & Aligoodarz, Lorestan & $95 \mathrm{ab}$ \\
\hline 24 & Lamard, Fars & $70 \mathrm{a}-\mathrm{d}$ & 59 & Noor Abad, Lorestan & $85 \mathrm{a}-\mathrm{c}$ \\
\hline 25 & Lar, Fars & $80 \mathrm{a}-\mathrm{c}$ & 60 & Alashtar, Lorestan & $85 \mathrm{a}-\mathrm{c}$ \\
\hline 26 & Kazeroon, Fars & $100 \mathrm{a}$ & 61 & Nahavand, Hamedan & $85 \mathrm{a}-\mathrm{c}$ \\
\hline 27 & Lar, Fars & $95 \mathrm{ab}$ & 62 & Bahar, Hamedan & $55 \mathrm{c}-\mathrm{f}$ \\
\hline 28 & Lar, Fars & $95 \mathrm{ab}$ & 63 & Bahar, Hamedan & $30 \mathrm{f}-\mathrm{h}$ \\
\hline 29 & Kazeroon, Fars & $100 \mathrm{a}$ & 64 & Kabudr ahang, Hamedan & 65 a-e \\
\hline 30 & Lar, Fars & $55 \mathrm{c}-\mathrm{f}$ & 65 & Aman abad, Hamedan & $5 \mathrm{ij}$ \\
\hline 31 & Dehgolan, Kordestan & $30 \mathrm{f}-\mathrm{h}$ & 66 & Nahavand, Hamedan & $100 \mathrm{a}$ \\
\hline 32 & Dehgolan, Kordestan & $85 \mathrm{a}-\mathrm{c}$ & 67 & Kabudr ahang, Hamedan & $55 \mathrm{c}-\mathrm{f}$ \\
\hline 33 & Ghorveh, Kordestan & $95 \mathrm{ab}$ & 68 & Aman abad, Hamedan & $90 \mathrm{ab}$ \\
\hline 34 & Dehgolan, Kordestan & $100 \mathrm{a}$ & 69 & Aman abad, Hamedan & $55 \mathrm{c}-\mathrm{f}$ \\
\hline 35 & Ghorveh, Kordestan & $95 \mathrm{ab}$ & 70 & Bahar, Hamedan & $95 \mathrm{ab}$ \\
\hline
\end{tabular}

شدت ه و جدايه اصفهان-1 | با شدت صفر درصد (غيربيماريزا) پايينترين شدت بيمارىزايى را نشان دادند (جدول (). ميانكين شدت بيمارىزايى جدايههاى استانهاى مختلـف نيـز مـورد بررسـى قـرار

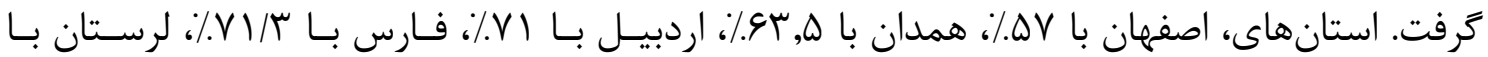

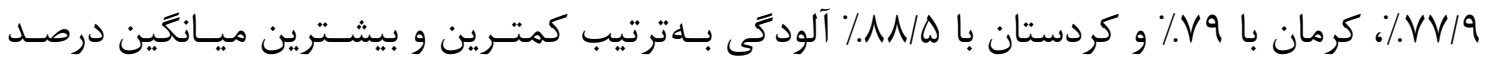

$$
\text { شدت بيمارى را در برابر جدايههاى مورد بررسى نشان دادند. }
$$




\section{Discussion}

عامل بيمارى يوسيدگى ريشه سيبزمينى داراى تنوع زنتيكى و ريختشناسى زيادى است علاوه بر خصوصيات زنتيكى اين قارج، عوامل ديكرى مانند تناوب محصولات، شرايط آب و هوايى و ارتفاع Yanar et al. ) متفاوت مناطق كاشت نيز در تنوع بيمارىزايى و خصوصيات اين قارج نقش دارند 2005). يافته ها مربوط به اين يزوهش نيز نشان مىدهد كه شدت بيمارىزايى در جدايههاى مختلف مربوط به نواحى مختلف آب و هوايى متفاوت است. تعيين شدت بيمارى، جدايههاى آزمون را بهطور واضح و روشنى از نظر توسعه و روند بيمارى از يكديكر تفكيك نمود. اين بيمارى در تمامى مناطق Al-Abedy et al. 2018, Balali et al. 2007, ) مختلف كشت اين كياه در ايران كزارش شده است Forghani et al. 2016 يافتههاى اين يزوهش نشان داد كه شدت بيمارىزايى بهطور معنادارى در جدايهها متفاوت بود (بين · تا • • ا درصد) بهطورى كه تعداد وع جدايه اين قارج باعث بيمارىزايى و ايجاد شانكر خشك ساقه در رقم بورن شدند. تنها جدايه شماره 11 از منطقه دامنه اصفهان بر روى رقم سيبزمينى بورن بيمارىزا نبود. جدايههاى مورد بررسى در اين يزوهش از قسمتهاى مختلف كياه سيبزمينى شامل شانكر ساقه، شانكر استولون و غده جداسازى شدند. جدايه شماره 11 كه بر روى رقم سيبزمينى بورن بيمارىزا نبود، از قسمت شانكر استولون جداسازى شده بود. طبق بررسى هاى كارلينگ و همكاران (• (199) نشان مىدهد كه بيمارىزايى جدايههاى R. solani روى رقمها مختلف سيبزمينى بسته به محل جداسازى عامل بيمارى مىتواند متفاوت باشد بهطورى كه يزوهشات نشان داده جدايههايى كه از شانكر جدا مىشوند نسبت به جدايههايى كه از اسكلروتها به دست مى آيند، بيمارىزايى كمترى دارند (Carling et al. 1990). البته طبق بررسى درصد بيمارى در استانهاى مختلف، جدايههاى مربوط به استان اصفهان داراى كمترين درصد بيمارىزايى يعنى درصد بوده است. همجنين مشخص شد كه جدايههاى استانهاى كرمان و كردستان داراى بيشترين درصد بيمارىزايى بودند. در يزوهشى مشابه بر روى جدايههاى اين بيمارى، يافته ها آزمون نشان داده كه درصد بيمارىزايى در جدايههاى مختلف متفاوت مىباشد و بيشترين درصد بيمارى در رقمم آكريا

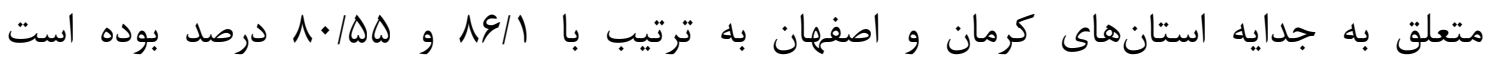

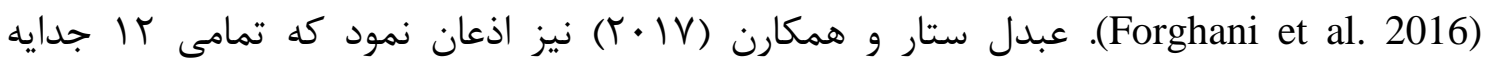
R. solani

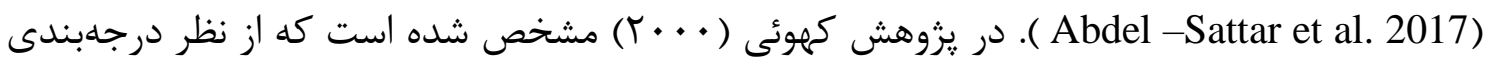
مقاومت رقمها (بين صفر تا نه) -9 بالاترين درجه مقاومت- درجه مقاومت رقم سيبزمينى بورن نسبت به شورهسياه عدد V مىباشد (Kehoei 2000). محققين متعددى مقاومت رقم سيبزمينى 
NasrollahNejad et al. بورن نسبت به ساير بيمارىهاى گياهى را مورد بررسى قرار داداند. (2013) ارزيابى مقاومت به سويه معمولى ويروس Y سيبزمينى (PVYO) در شرايط كلخانه مورد بررسى قرار داده و به اين نتيجه رسيدند كه رقم بورن عليرغم اينكه بالاترين غلظت ويروس را داشت ولى از نظر شاخص درجه نشانه، حساسيت زيادى را نسبت به ساير رقمهاى مورد آزمايش نشان نداد. شدت بيمارى يوسيدگى خشك سيبزمينى را در انبارهاى مختلف Roohi Bakhsh et al. (2016) شهرستان اردبيل مورد بررسى قرار داده و به اين نتيجه رسيدند كه رقم بورن داراى كمترين ميزان

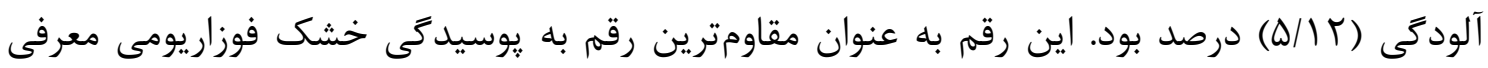

\section{Conclusion}

يافتههاى اين يزوهش نشان داد كه رقم بورن مىتواند بهعنوان يك رقم ييشنهادى در منطقههاى كشت سيبزمينى در استانهاى اصفهان و همدان توصيه شود. با توجه به كشت بهاره و ميانرس بودن اين رقم بهخصوص در استانهاى موردنظر كه معمولاً سيبزمينى در مناطق سردسير اين استانها كشت مىشود مىتواند بهعنوان يكى از ززينهها جهت كشت انتخاب شود. البته شدت بيمارىزايى هر جدايه تحت شرايط آب و هوايى، نوع رقم و حساسيت آن، تناوب زراعى و ساير شرايط زراعى متفاوت است. با توجه به مقاومت اين رقم نسبت به انباردارى و برخى از بيمارىهاى قارجى و ويروسى عنوان شده، استفاده از اين رقم در برنامههاى تناوب زراعى همراه با كاربرد ساير روشهاى

$$
\text { مديريتى بيمارى توصيه مىشود. }
$$

\section{References}

1. Abdel-Sattar M, El-Marzouky H, Ibrahim U (2017) Pathogenicity test and anastomosis group of Rhizoctonia solani the causal organism of stem canker and black scurf disease of potato in Egypt. Journal of Applied Plant Protection 6:1-8.

2. Al-Abedy AN, Al-Fadhal FA, Karem MH, Al-Masoudi Z, Al-Mamoori SA (2018) Genetic variability of different isolates of Rhizoctonia solani Kühn isolated from Iranian imported potato tubers (Solanum tuberosum L.). International Journal of Agricultural Statatistic Science 14:587-598.

3. Balali GR, Neate SM, Kasalkheh AM, Stodart BJ, Melanson DL, Scott ES (2007) Intraspecific variation of Rhizoctonia solani AG 3 isolates recovered from potato fields in Central Iran and South Australia. Mycopathologia 163:105-115.

4. Banville GJ, Carling DE, Otrysko BE (1996) Rhizoctonia Disease on Potato. Pp: 321-330, In: Sneh B., Jabaji-Hare S., Neate S., Dijst G. (eds) Rhizoctonia 
Species: Taxonomy, Molecular Biology, Ecology, Pathology and Disease Control. Springer, Dordrecht, Germany

5. Bartz FE, Cubeta MA, Toda T, Naito SH, Ivors KL (2010) An in planta method for assessing the role of basidiospores in Rhizoctonia foliar disease of tomato. Plant Disease 94:515-20.

6. Carling DE, Leiner RH (1990) Virulence of isolates of Rhizoctonia solani AG-3 collected from potato plant organs and soil. Plant Disease 74:901-3.

7. Fiers M, Edel-Hermann V, Heraud, C (2011) Genetic diversity of Rhizoctonia solani associated with potato tubers in France. Mycologia 103:1230-1244.

8. Forghani D, Nase Esfahani M, Bazgir E (2016) Biodiversity of national isolates of Rhizoctonia solani causing dry canker and black scurf. $22^{\text {nd }}$ Iranian Plant Protection Congress.

9. Ganeshamoorthi P, Dubey SC (2013) Phylogeny analysis of Indian strains of Rhizoctonia solani isolated from chickpea and development of sequence characterized amplified region (SCAR) marker for detection of the pathogen. African Journal of Microbiological Researches 7:5516-5525.

10. Haghighati B, Bromand Nasab S, Naseri A (2016) Effect of irrigation water amount bon yield, some qualitative characteristics and water productivity of two potato cultivars. Crop Physiology Journal 7:45-60.

11. Kuninaga SH, Carling DE, Takeuchi T, Yokosawa R (2000) Comparison of rDNA-ITS sequences between potato and tobacco strains in Rhizoctonia solani AG3. Journal of General Plant Pathology 66:2-11.

12. Moghaddam GA, Rezayatmand Z, Nasr Esfahani M, Khozaei M (2019) Genetic defense analysis of tomatoes in response to early blight disease, Alternaria alternata. Plant Physiology and Biochemistry 142:500-09.

13. Nasrollah Nejad S, Zinati Fakhrabad F (2013) Evaluation of resistance to normal strain of Potato Y Virus (PVY) in four potato cultivars under greenhouse conditions. Journal of Plant Disease Research 1:24-19 (In Persian with English Abstract).

14. National Institution of Agriculture Botany (NIAB) (1985) Diseases Assessment Manual for Crop Variety Trials. Cambridge, UK.

15. Prasad B, Eizenga GC (2008) Rice sheath blight disease resistance identified in Oryza species accessions. Plant Disease 92:1503-1509.

16. Roohi Bakhsh A, Moosa nezhad S, Khoshnevis L (2016) The potato dry rot causal agent and severity in Ardabil storages and the resistance of cultivars to the disease. Biological Journal of Microorganisms 5:183-202.

17. Spooner DM, McLean K, Ramsay G, Waugh R, Bryan GJ (2005) A single domestication for potato based on multilocus amplified fragment length polymorphism genotyping. Proceedings of the National Academy of Sciences of the United States of America 102:14694-14699.

18. Stevenson WR, Loria R, Franc GD, Weingartner DP (2001) Compendium of Potato Diseases. APS Press, Minnesota, USA.144p. 
19. Woodhall JW, Lees A, Edwards SG, Jenkinson P (2008) Infection of potato by Rhizoctonia solani: Effect of anastomosis group. Plant Pathology 57:897-905.

20. Yanar Y, Yilmaz G, Cesmeli, I (2005) Characterization of Rhizoctonia solani isolates from potatoes in turkey and screening potato cultivars for resistance to AG-3 isolates. Phytoparasitica 33:370-376. 